\title{
Modal analysis and stiffness optimization: the case of ceramic tile finishing
}

\author{
A. Pavlović ${ }^{*}$, C. Fragassa ${ }^{1}$, F. Ubertini ${ }^{1}$, A. Martini ${ }^{1}$
}

${ }^{1}$ Alma Mater Studiorum University of Bologna, Interdepartmental Industrial Research Centre of Advanced Applications in Mechanical Engineering and Materials Technology, Viale

Risorgimento 2, 40136 Bologna, Italy

e-mail: ana.pavlovic@unibo.it

e-mail: cristiano.fragassa@unibo.it

e-mail: francesco.ubertini@unibo.it

e-mail: alberto.martini6@unibo.it

*corresponding author

\begin{abstract}
Considering the customers' demand for high quality products, surface finishing represents an extremely delicate phase in the production of ceramic tiles. In these terms, stiffer machinery can be considered a practical response to the need of accurate manufacturing processes. This research is focused on investigating and improving the (elasto)dynamic behaviour of a large machine tool, used for polishing and lapping ceramic tiles. A modal analysis was realized comparing natural frequencies in respect to different design solutions. The stiffness optimization was obtained by changing the structural design.
\end{abstract}

Keywords: Grés porcelain, process quality, machine design, vibration, finite element, ANSYS

\section{Introduction}

Vibrations represent a potential issue to deal with during the design phase of productive plants, automatic machines and other high-performance machineries (e.g. Altintas 2012, Liang 2013, Martini 2016, Sam Paul 2016) given their relevance in terms of quality of processes and products; particularly, being crucial in the case of ceramic technology (Fragassa 2015).

As for machine tools, three main sources of vibration phenomena can be distinguished. Firstly, cutting forces can excite the system in a wide spectrum (given by the spindle rotation velocity, the tooth passing frequency and their harmonics) and induce high vibration levels and chatter phenomena (Altintas 2004). Secondly, the high inertia actions, associated with rapid movement for cutting tool or laser head positioning, can cause vibrations by triggering the natural frequencies and mode shapes of the machinery (Troncossi 2009). Finally, vibrations generated in other sections of the manufacturing plant may propagate to the machine tool and excite its resonances, affecting the working performance (Wang 2005, Wójcicki 2015).

In particular, high vibration levels can induce several detrimental effects on tool cutting. Large oscillations of both the machining head and the machine structure are expected to reduce the quality of machining operations and to determine a considerable increment in the amount of 
nonconforming products, hence heavily reducing the plant production capacity, and consequently raising the energy requirements to achieve the target production volume. In addition, severe vibrations may entail significant wear and durability issues primarily involving the bearings and the other components of mechanical power transmission chains.

Last but not least, vibrations affecting the machine moving parts also cause oscillations in the loads required to drive the actuators with the desired laws of motion, which result in overloads and higher power consumption.

Based on the above considerations, limiting vibrations appear an essential goal to reduce maintenance costs, minimize losses for nonconforming products (Fragassa 2016) and enhance energy efficiency of machine tools.

Virtual testing represents a suitable tool to predict the dynamic behaviour of ceramic processes (Pavlovic et al. 2016), including machine tooling, and to assess possible vibration issues. In particular, the implementation of numerical models based on finite element analysis has been proven to be effective for this purpose, which is typically a challenging task due to the complexity of such mechanical systems (Zanarini 2002, Troncossi 2009).

Indeed, this numerical approach may permit to identify the most critical parts or units without the need for a physical prototype, hence guiding the optimization of machine tools from the early phases of the mechanical design process.

Each active electric or internal combustion motor generates vibration due to the inertia of the moving masses and its unbalanced internal components. The vibrations can be simply annoying or, beyond a certain limit, represent a source of stress/failure for machine structures or for products in the case of manufacturing machines.

Vibrations are commonly divided in free vibrations and excited vibrations.

Free vibrations occur when a mechanical system vibrates without being subjected to any external force. A system, not subjected to forces, vibrates based on its initial conditions (displacement, speed and acceleration), which are different from zero. Or, in another perspective, at a certain instant the system is in a condition different than that of balance. A typical example is a spring-mass system that is moved from the rest condition. Ideally, if this kind of system is not subjected to any kind of friction, damping or energy loss, it would continue to vibrate indefinitely.

Instead, in excited (or forced) vibrations, the vibrations are present in the mechanical system only when an external force excites it. Among the system excitations, it is necessary to include not only all the external forces, but also each movement of the system constraints. This article will mainly deal with excited vibrations, which constitute the vast majority of real situations.

In real (continuous) systems, each infinitesimal part of a body has inertial, elastic and dissipative characteristics at the same time. These systems can be seen as discrete systems with an infinite number of degrees of freedom. A beam wedged steel, for instance, can be discretized in a very large number of infinitesimal elements. Each of these elements is characterized by a mass, with its own stiffness and damping. Thus, the analysis of continuous systems can start from the study of the behaviour of the most infinitesimal part of a beam. In this case of an infinitesimal part, the vibrations can be simplified into: flexural, torsional and related to a periodical excitation (Cveticanin 2012). The vibration modes may be also found for this simple case using theoretical solutions, described by imposing the boundary conditions wherein the beam is subject to extremes. In particular, it is necessary to require that the deformation is null at the ends of the beam where a state of equilibrium is also present. Each deformed solution coincides with a mode of vibration. 
Although in the case of an infinitesimal beam only three ways of deformation exist, a continuous system presents infinite number of modes of vibration. Thus, without using a Finite Element (FE) code, any analysis of real complex geometries, differently by simplified ones (e.g. Cetkovic and Vuksanovic 2012 for plates), is practically impossible as reported in Mackerle (1999 and 2003). On the contrary, accepting a FE approach, a modal analysis can easily provide useful information on the dynamical behaviour of geometrically complex systems towards a better comprehension of its functionality (Assefa 2013).

The modal analysis can be used to determine the vibration characteristics (in terms of natural frequencies and mode shapes) of machine structures or machine parts, even during their design phase. It can also serve as a starting point for other and more detailed dynamic investigations, as transient dynamic analysis, harmonic analysis or spectral analysis.

Furthermore, it is possible to easily perform a modal analysis on a pre-loaded structure, or to benefit from symmetric patterns. The information and results provided by FEA can be really useful in designing by orienting a system optimization. Altogether, the modal analysis can:

Provide an idea on how structures respond to specific dynamic loads;

Permit to design structures with the aim at avoiding phenomena of resonances or at offering an optimized response in respect to specific frequencies;

Support the correct estimation of fundamental parameters (e.g. time steps), necessary for further dynamic analysis.

Although the significant power offered by simulation codes considering that the vibration modes quickly increase in complexity together with the geometrical complexity, in the case of continuous systems it is a common practice to limit the modal investigation to a little number of significant frequencies, as mentioned in Mahnama (2010 and 2012), Nance (2002), Negahban (2014) and Mourtzia (2014).

Progresses in production of machines for processing porcelain stoneware tiles become more integrated with more controller, performance and working accuracy. The desire for a better surface finish of a work piece results in a more accurate operation, leading to the need for a much more precise, stable and vibration-less machine. To solve these problems, the vibration of a machine tool should be measured and analysed with the aim to identify the source of vibration and to make it possible to modify or redesign the structure towards a vibration-less and chatter-less performance (Okubo 1982). As demonstrated in this paper, the modal analysis represents a highly powerful mean to support the structure design of machining tools regarding dynamic rigidity. The natural frequencies, damping ratios and mode shapes of machine structures can be accurately measured by applying modal analysis as stated by Snoeys (1979), Peters J (1976), Mießen M (1976), Tlusty J (1976). The effective information for modification can be obtained by visual study of the animated mode shapes with an intention of finding out specific points where the improvement should be made on the structure.

\section{Polishing and Lapping system}

The current research is focused on improving the dynamic behaviour of a large machinery used for (super) finishing porcelain stoneware tiles by changes in the structural design. The machine, represented in Fig. 1, uses a tool cutting process for polishing and then lapping the surfaces. 

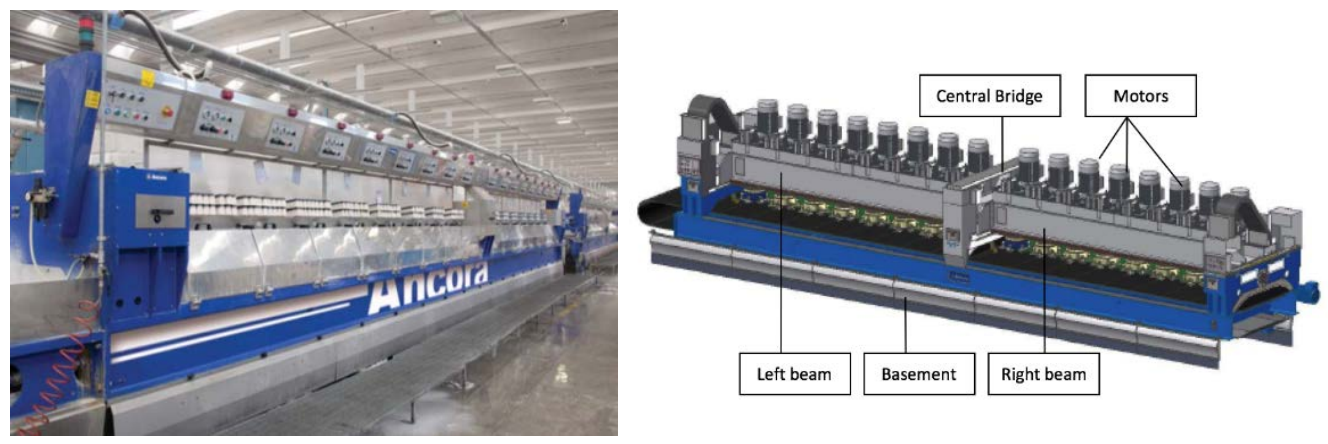

Fig. 1. Machine for tile surface finishing (polishing and lapping)

According to this double step manufacturing, the machine tool can be conveniently divided into five structural subgroups:

1. Basement

2. Left beam (for polishing)

3. Central bridge

4. Right beam (for lapping)

5. Motors

The basement is made of heavy structure, realized by electro-welded steel parts, sandblasted and painted with special anti-corrosive paints. It mainly consists of a stainless steel flat and rigid support, worked with centesimal precision, on which special plates are applied with the aim to facilitate the sliding of the conveyor belt on an anti-wear material, applied with screws for an easy replacement during maintenance.

A swinging motion of the planetary heads containing the abrasive fickerts on the ceramic tiles realizes the polishing and lapping processes. Two heavy beams, transversally oscillating, operate this movement. Speeds are controlled in order to meet every kind of manufacturing requirement.

A perfect polishing requires intense forces on the ceramic material, but also a progressive treatment; thus a specific design solution is developed consisting in several cutting heads. Each head, 16 in total, exercises a force of $2480 \mathrm{~N}$ on the tile, obtained by pneumatic pistons. These heads, each one powered by six oscillating abrasive fickerts, can reach the overall pressure of 4 bar (Fig. 2). The lapping stage requires less intense machining and there is a tendency to use the planetary head unit as a counter pressure element, which exerts less weight on the tile. The polishing and lapping abrasive fickerts can be easily adjusted in seven different positions to adapt to particularly challenging surfaces. 

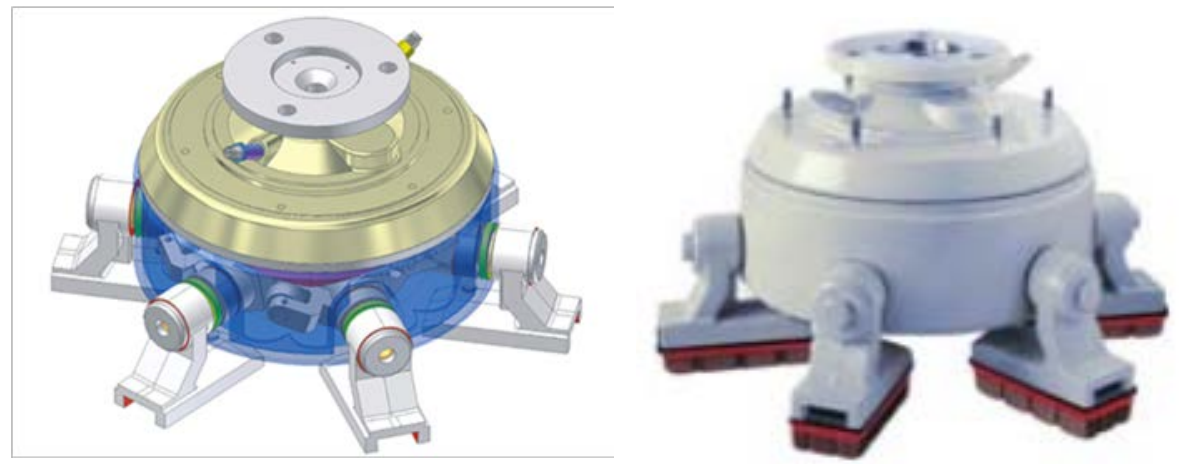

Fig. 2. Planetary head with abrasive fickerts for surface finishing

The overall weight of the machine is $15360 \mathrm{~kg}$, where $2000 \mathrm{~kg}$ represents the mass of each oscillating beam, while the 16 motors weight about $300 \mathrm{~kg}$ each, with $85 \mathrm{~kg}$ of abrasive fickerts. The movement for these heavy beams is described by the sinusoidal law (Fig. 3) with reverse motion on the extremes, a maximum speed of $0.42 \mathrm{~m} / \mathrm{s}$, a maximum acceleration of $0.387 \mathrm{~m} / \mathrm{s}^{2}$ and a maximal excursion of $0.9 \mathrm{~m}$ reached in $3.5 \mathrm{~s}$.

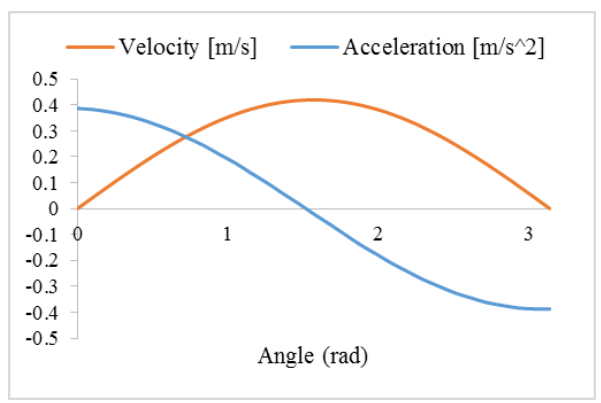

Fig. 3. Law of motion of the machine for tile polishing

\section{Numerical approach}

To prevent the risk to develop extremely complex numerical models that do not represent the real system, it is necessary to simplify the preliminary structure, as reported in Marten (1962) and Zatarain (1998). Basically, the system can be divided into functional subgroups, linked to each other by lumped masses or other parameters. Adding, it is noteworthy to highlight that some components show highly non-linear behaviour.

In general, several software applications for finite element analysis can be conveniently used for performing modal analysis, described by Canair (2005), Mahdavinejad (2005), Kehl (2015), Myers (2003) and Raman (1984). In this study, ANSYS Workbench V.16 was preferred as described in similar studies of Karagülle (2004) and Kang (2005). In ANSYS, as in the majority of other software tools, the modal analysis is linear, i.e. any non-linearity in materials (e.g. plasticity) or in the system (e.g. contacts between elements) is ignored even if correctly defined in the pre-processor. 
Among the various direct methods, The Eigen Structure Assignment Method was preferred and applied as explained in Rad (1997). The basic approach is adapted from the control theory and the updated model is expected to reproduce a number of measured modes exactly.

Consider the equation of motion for a system containing $\mathrm{N}$ degrees of freedom:

$$
\left[M_{A}\right]\{\ddot{X}\}+\left[C_{A}\right]\{\dot{X}\}+\left[K_{A}\right]\{X\}=\left[B_{O}\right]\{U\}
$$

where $\{U\}$ is the input force vectore and the matrix $\left[\mathrm{B}_{0}\right]$ determines the location of forces on the structure. An arbitrary output $\{Y\}$ can be considered as the combination of displacements and velocities:

$$
\{Y\}=\left[D_{O}\right]\{X\}+\left[D_{1}\right]\{\dot{X}\}
$$

In control applications, the problem is usually to find the feedback matrix, [G], such that:

$$
\{U\}=[G]\{Y\}
$$

which ensures that the closed loop system has the descried eigenvalues and eigenvectors. Combining the above equations, the result for the updated stiffness and damping matrices is:

$$
\begin{aligned}
{\left[K_{U}\right] } & =\left[K_{A}\right]-\left[B_{O}\right][G]\left[D_{O}\right] \\
{\left[C_{U}\right] } & =\left[C_{A}\right]-\left[B_{O}\right][G]\left[D_{1}\right]
\end{aligned}
$$

where the matrix $\left[B_{0}\right]$ can be arbitrarily chosen. The matrices $\left[D_{0}\right]$ and $\left[D_{1}\right]$ must be chosen such that $\left[D_{1}\right]\left[\Phi_{X}\right]\left[\Lambda_{X}\right]+\left[D_{0}\right]\left[\Phi_{X}\right]$ is invertible. The matrices $\left[\Lambda_{X}\right]$ and $\left[\Phi_{X}\right]$ are the experimentally derived eigenvalues and eigenvectors that are to be assigned to the initial structural model. Using expanded mode shape, the matrix $[G]$ is determined as:

$$
\begin{gathered}
{[G]=\left(\left[M_{A}\right]\left[B_{0}\right]\right)\left(\left[\phi_{X}\right]\left[\Lambda_{X}^{2}\right]+\left[M_{A}\right]^{-1}\left[C_{A}\right]\left[\phi_{X}\right]\left[\Lambda_{X}\right]+\left[M_{A}\right]^{-1}\left[K_{A}\right]\left[\phi_{X}\right]\right)} \\
\left(\left[D_{1}\right]\left[\phi_{X}\right]\left[\Lambda_{X}\right]+\left[D_{0}\right]\left[\phi_{X}\right]\right)
\end{gathered}
$$

\section{Modelling procedures}

The theoretical study of the vibratory system was divided passing by the definition of:

1. Physical model: schematic model made starting from the analysis of the actual vibrating structure.

2. Mathematical model: transposition in the form of mathematical expressions of the physical model; in particular, the mechanical vibration is transposed into mathematical formulations, based on differential equations and representing the analytical links between the movements of the points on the structure and the derivatives of the same movements, usually up to the second order.

3. Lumped models: summarize the structure as if it was composed by several elements, primarily focused on the mechanical properties. Elements only assume inertial characteristics and other massless properties, such as strength. Their mathematical model is based on ordinary differential equations.

4. Continuous models: mechanical properties are assigned wherever they may be, that is inside the body, point by point of its volume. Their mathematical model is based on partial differential equations.

The physical model can be developed using traditional techniques or automatic discretization. Traditional techniques are based on concentrated or distributed parameters, and commonly used for very simple structures where solid mechanics theories can be easily applied. 
Otherwise, differential equations cannot be solved in closed form. In this case, as for the machine tool under investigation, the finite element method is in-between the other techniques. In fact, it allows adopting a physical model distributed parameter, in the sense that the geometry is taken from the real system. However, this geometry is divided into a number of elements in the way to discretize the continuous space.

\subsection{Create a model}

With the aim at creating the finite element model with the intention to perform a modal analysis by ANSYS, the following conditions were taken into consideration:

- Only linear behaviour was considered inside the analysis;

- If non-linear elements were specified, they were treated as linear. For example, in contact elements the stiffness was calculated according to their initial state and never changed. For modal analysis with pre-load, the code assumed that the initial state of the contact elements was the state upon achievement of static analysis preloaded;

- Material properties could be linear, isotropic or orthotropic, constant or a function of temperature;

- $\quad$ Both the module of elasticity (or stiffness in some form) and the density (or mass in some form) had to be defined; non-linear properties were ignored;

If damping elements were applied, real constants required for each specific element should be defined.

\subsection{Application of constrains}

Following the model definition, the finite element analysis involved the steps of:

1. Defining the analysis type and options;

2. Making the grid of finite elements;

3. Applying constraints and loads;

4. Specifying the calculation options;

5. Solving.

The finite element mesh spatially discretized the geometry into elements and nodes. This mesh, with properties of applied materials, was used to mathematically represent the rigidity and the mass distribution of the structure. A proper finite element size was determined based on a number of factors including the overall size of the model, the proximity of other topologies, curvatures of the body, and the complexity of the function. When necessary, the fineness mesh was adjusted to obtain a better approximation at the local level.

The only conditions influencing the modal analysis are constraints related to displacement. Whatever is the value of displacement, the program assigns a constraint with a zero value and appropriate degree of freedom. For directions in which constraints are specified, the program considers the system as a rigid body.

\subsection{Modal analysis}

This research was focused on investigating the effect of design changes in machine stability and involved two different structures in comparison: 
- Model No. 1: the original solution of machine, with a very simple swinging beam and standard engine support with rigid central and lateral beams.

- Model No. 2: an improved solution of the machine with new swinging beam and adequate engine support with lighter central and lateral beams.

The 3D geometries of these structures were imported in ANSYS as .stp files. A simplification of basements and other structural elements were realized before meshing (Fig. 4). Meshes of finite elements were created with uniformity in element distribution for the largest elements of the structures, while a finer mesh was preferred closer to relatively small parts and sections, as shown in Fig. 5. About 2 million nodes and 650000 elements were used. Boundary conditions were applied simplifying several physical conditions. In particular, the planetary heads with abrasive fickerts, including their engines, were substituted by lumped masses equal to $300 \mathrm{~kg}$ each. A condition of infinite rigid floor is also used as constraint.

Material properties, such as elasticity modulus, Poisson ratio and density were introduced considering the specific steel used in constructions.

Modal analysis output consists in the evaluation of natural frequencies, mode shapes and participation factors. The participation factors, or eigenvalues, represent the coefficients for the eigenmodes of the structure. They deal with the mass distribution for each deformed condition.

In Fig 6, the natural frequencies for both models are reported. It is also noteworthy that, in accordance with several considerations on plants and processes, only natural frequencies lower than $50 \mathrm{~Hz}$ can significantly affect the regular operation of machines.
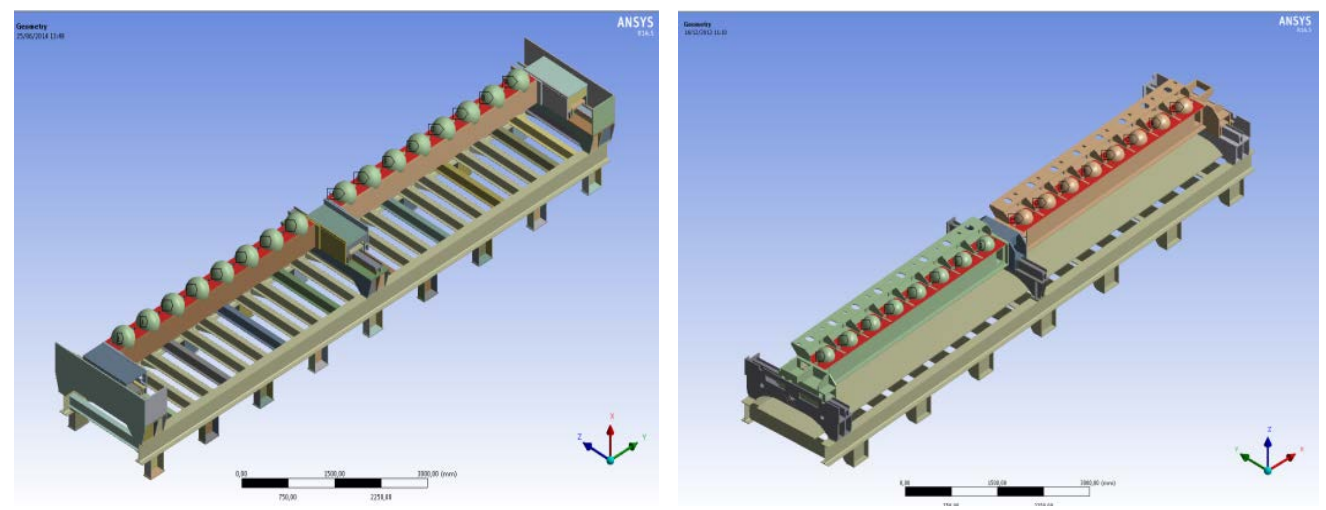

Fig. 4. Simplified geometry of comparative design solutions 

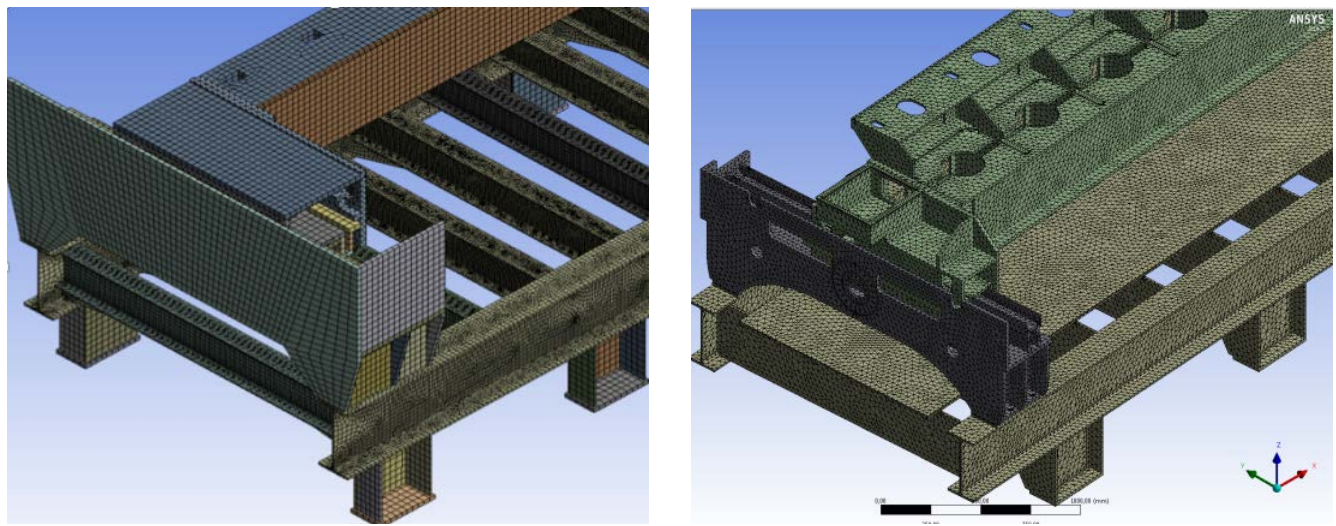

Fig. 5. Details of mesh refinement for different design solutions
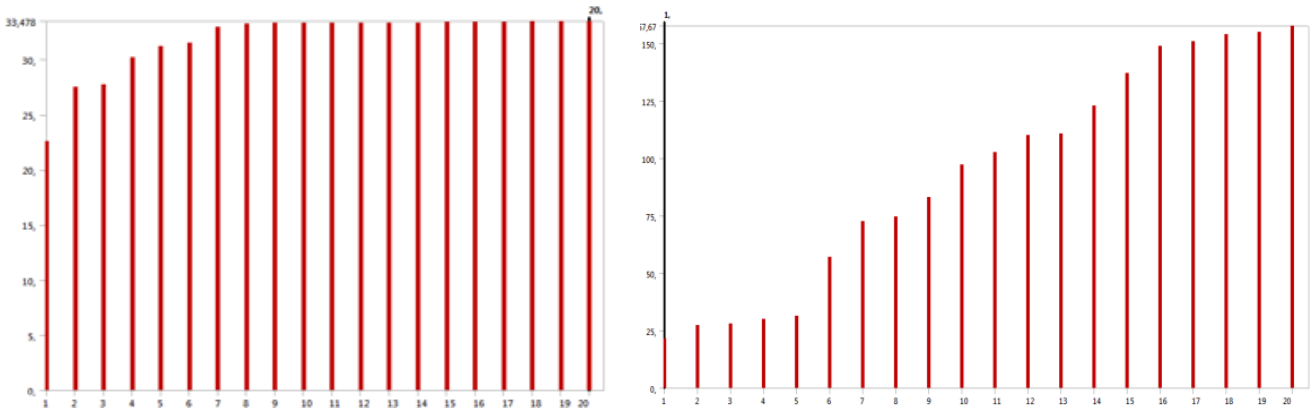

Fig. 6. Natural frequencies for different design solutions

\section{Results and Discussion}

Comparing the output in terms of natural frequencies (Fig. 6), several considerations emerged. Regarding the original design Model No. 1:

- $\quad$ Natural frequencies up to 6th are quite similar, ranging between $22 \mathrm{~Hz}$ and $32 \mathrm{~Hz}$;

- $\quad$ Starting from the $7^{\text {th }}$, the frequencies are nearly overlapped at approximately $33 \mathrm{~Hz}$.

It also means, that practically the whole range of frequencies, as estimated, can set the structure in condition of resonance, affecting the machine stability.

For the improved design Model No. 2:

- $\quad$ The first 5 natural frequencies are also concentrated between $21 \mathrm{~Hz}$ and $33 \mathrm{~Hz}$;

- $\quad$ Starting from the $6^{\text {th }}$, all the natural frequencies are higher than $50 \mathrm{~Hz}$.

I.e. the machine stability is increased by changes in geometries, while the resonance phenomena can be better managed. 

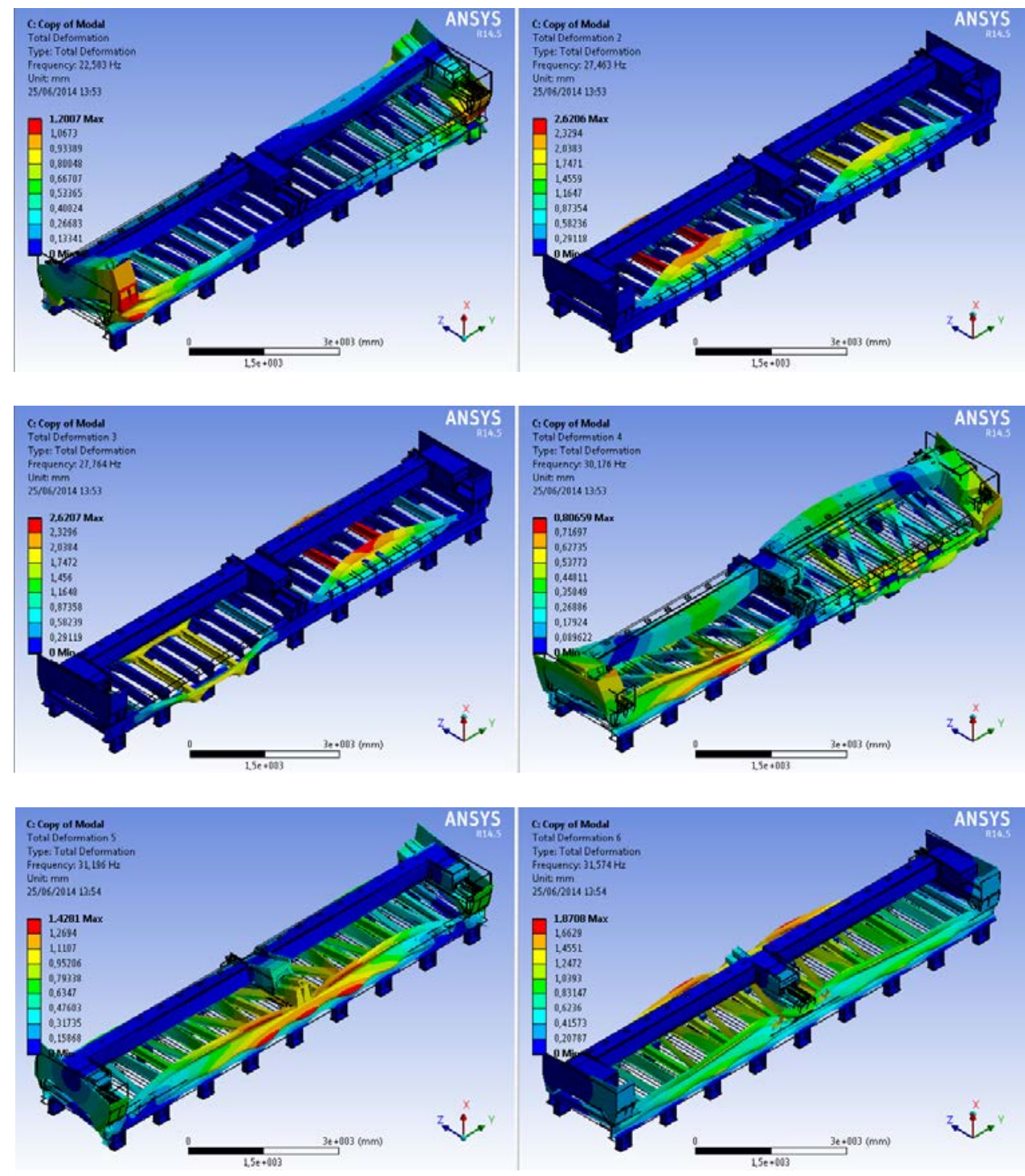

Fig. 7. Six first natural modes of vibration of the original machine model

Investigating the vibration modes for both structures by the related deformations (as displayed in Fig. 7 and 8 for six first modes), it is possible to note that:

- The original design presents a large variety of geometrically deformed configurations, but these changes mainly involve the basement;

- $\quad$ The improved design focuses these deformed configurations on beams, changing their geometries on a not-deformed basement. 

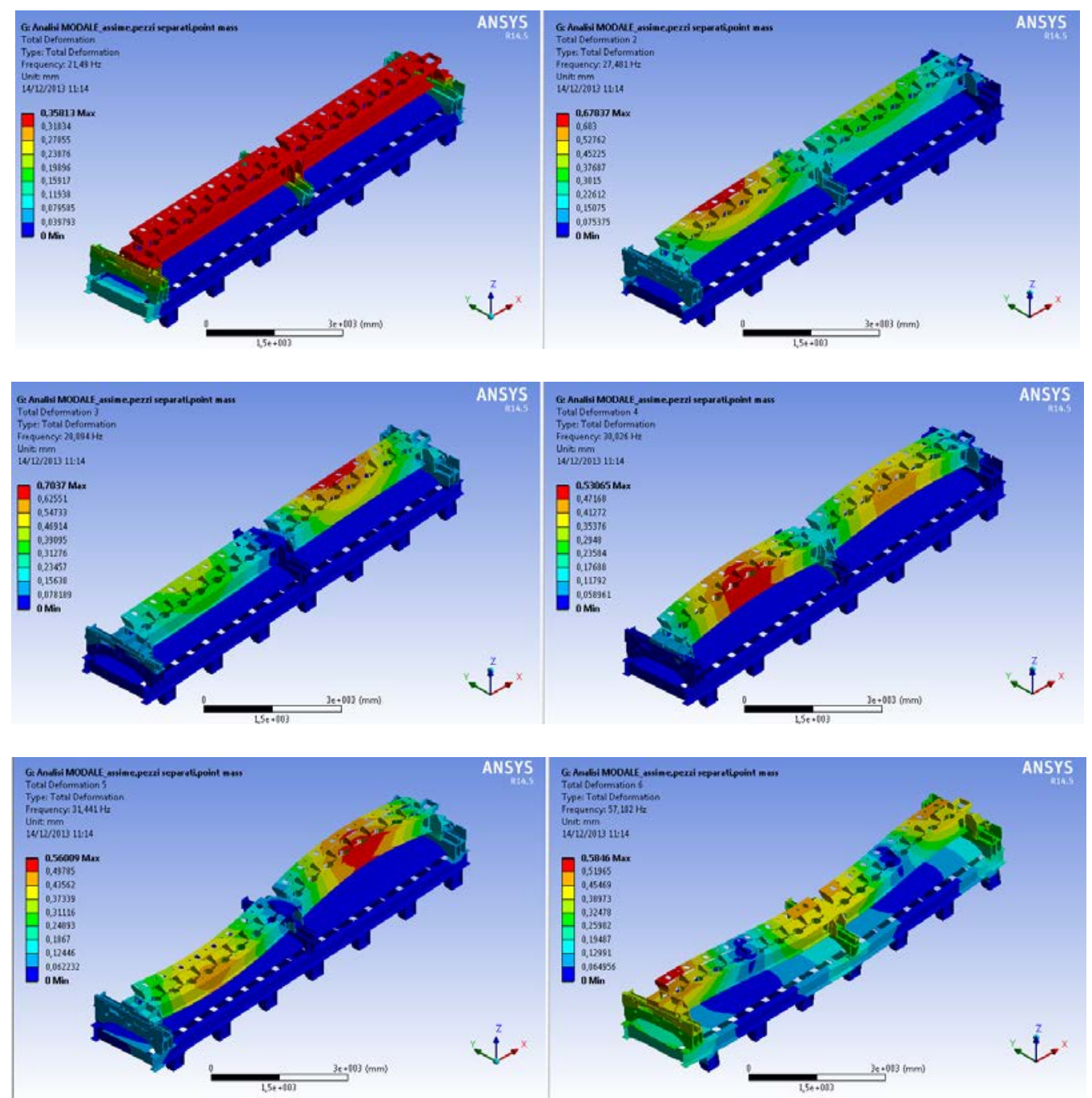

Fig. 8. Six first natural modes of vibration of the improved machine model

In particular, the $1^{\text {st }}$ vibrational mode for the improved design shows the bending effect of the whole swinging beam structure, used as locked part for fixing and movement of the rotating head of the polishing machine. This part is already in fast motion in respect to the frame, with a periodic movement and control. Consequently, it is considered that these additional oscillations, linked to oscillation modes that are in any case referenced to a single body movement, do not impact neither the machine structure, nor the quality of the processing. It would be a completely different situation in the case of a swinging beam presenting a vibrational mode such as to differentiate the displacements in different zones of the beam itself. In this hypothesis, it would be impossible to guarantee an adequate machining quality.

Referring to the $2^{\text {nd }}$ and $3^{\text {th }}$ vibrational modes for the improved design, it should be firstly noted that, in practice, they correspond to each other, referring only to the oscillation of opposite sections of the same component (swinging beam). A further redesign of this component would lead to overcome the problem with respect to both modes. The same action 
would also solve the criticality showed by the $4^{\text {th }}$ vibrational mode and the following one. In fact, it is clear that all the initial modes of oscillation concern the swinging beam.

To uncover some configurations in the improved design connected to other machine components (e.g. basement), the $12^{\text {th }}$ mode of vibration with $103 \mathrm{~Hz}$ should be analysed.

In other words, even if the new improved model apparently maintains the same first resonance frequencies (around $21-32 \mathrm{~Hz}$ ), its stability with respect to vibrational phenomena is incomparably higher than the previous machine model.

In the original design, the presence of any phenomenon that is repeated 30 times per second causes a machine vibration from all sides. Basements in torsion ( $1^{\text {st }}$ mode), in rotation and in bending ( $4^{\text {th }}$ mode); basement support that bends ( $2^{\text {nd }}$ mode), enlarges ( $6^{\text {th }}$ mode) and inflects ( $3^{\text {th }}$ mode). In the improved design, the situation seems different with a more stable dynamic response. The only additional operation that would have to be done is on the swinging beam.

\title{
6. Conclusion
}

In the recent years, the massive use of numerical models has improved the possibility to investigate the static and dynamic behaviour of structures starting from the early design stage. The modal analysis, in particular, can provide an effective guideline for improving the dynamic response of complex productive machineries, such as machine tools used for tile finishing.

In this case, two design solutions were compared in terms of natural frequencies and modes, permitting to validate and optimise the structures in terms of vibrations. In particular, it was noted that, while the original design presents a larger gamma of geometries for deformed configurations, mainly involving the basement and its parts, the improved design focuses these deformed configurations on beams, which are fixed on an extremely stable basement. This second case presents several advantages with the aim at providing the highest quality in process or product. Furthermore, since criticalities are now concentrated on a specific part (beam), it is simpler to continue to improve the dynamic behaviour of the machine by additional design changes. A future investigation will be focused on the optimisation of the swinging beam design taking also in consideration a general reorganization of its operational mode.

Acknowledgments This research has been realized inside the project IPERCER with the aim at developing energy efficient solutions for the production of large porcelain stoneware tiles. The authors acknowledge the support of the European Union and the Region Emilia-Romagna (inside the POR-FESR 2014-2020, Axis 1, Research and Innovation).

Извод

\section{Модална анализа и оптимизација крутости: пример обраде керамичких плочица}

\author{
А. Павловић ${ }^{1 *}$, C. Fragassa $^{1}$, F. Ubertini ${ }^{1}$, A. Martini ${ }^{1}$ \\ ${ }^{1}$ Alma Mater Studiorum University of Bologna, Interdepartmental Industrial Research Centre \\ of Advanced Applications in Mechanical Engineering and Materials Technology, Viale \\ Risorgimento 2, 40136, Болоња, Италија \\ имејл: ana.pavlovic@unibo.it
}


имејл: cristiano.fragassa@unibo.it

имејл: francesco.ubertini@unibo.it

имејл: alberto.martini6@unibo.it

* главни аутор

\section{Резиме}

C обзиром на захтеве купаца за високим квалитетом производа, површинска обрада представља изузетно деликатну фазу у производњи керамичких плочица. Узимајући ово у обзир, крутоћа опреме може се сматрати практичним одговором на потребу за прецизношћу производних процеса. Ово истраживање се фокусира на истраживање и побољшање (еластично) динамичног понашања великих алатних машина, које се користе за хоновање и леповање керамичких плочица. Модална анализа је реализована упоређивањем природних фреквенција са различитим пројектним решењима. Оптимизација крутости је остварена променом пројектног решења.

Кључне речи: Grés порцелан, квалитет процеса обраде, дизајн машина, вибрације, FEM, ANSYS

\section{References}

Alexiou K, Wright J.R (1985). Determination of force distribution in multi point resonance testing using various direct methods, 2nd International Symposium on Aeroelasticity and Structural Dynamics, 553-564.

Altintas Y, Weck M (2004). Chatter stability of metal cutting and grinding, Annals of the CIRP, 53 (2), 619-642.

Altintas Y (2012). Manufacturing Automation: Metal Cutting Mechanics, Machine Tool Vibrations, and CNC Design, Cambridge University Press.

Assefa M (2013). Modal Analysis of Machine Tool Column Using Finite Element Method, International Journal of Mechanical, Aerospace, Industrial, Mechatronic and Manufacturing Engineering, 7, 4, 699-708.

Cakair CM, Yahya IS (2005). Finite element analysis of cutting tools prior to fracture in hard turning operations, Materials and Design, 26, 2, 105-112.

Cetkovic M, Vuksanovic D (2012). Vibrations of isotropic, orthotropic and laminated composite plates with various boundary conditions. Journal of the Serbian Society of Computational Mechanics, 6, 1, 83-96.

Cveticanin L (2012). A review on dynamics of mass variable systems. Journal of the Serbian Society of Computational Mechanics, 6, 1, 56-73.

Fragassa C (2016). Methodological details in modelling the viscoelastic response of ceramic materials by commercial Finite Elements codes. FME Transactions, 44, 1, 58-64

Fragassa C (2016). Flexural Testing Machine as an Off-Line Control System for Quality Monitoring in the Production of Bended Ceramic Tiles. International Journal for Quality Research, 10, 2, 373-388.

Fragassa C (2015). Limits in Application of International Standards to Innovative Ceramic Solutions. International Journal for Quality Research, 9, 2, 279-298

Kang Y and Han Tao (2005). The application of ANSYS in model analysis. Journal of Jiamusi University: Natural Science, 23, 1, 81-84. 
Karagülle H, Malgaca L and Öktem H F (2004). Analysis of active vibration control in smart structures by ANSYS. Smart Materials and Structures, 13,4, 661.

Kehl G, Blank D (2015). Finite Element Analysis Simulation of Machine Tools with Integrated Drive Control, Applied Mathematics and Materials, 13-16.

Liang Y, Chen W, Bai Q, Sun Y, Chen G, Zhang Q, Sun Y (2013). Design and dynamic optimization of an ultraprecision diamond fly cutting machine tool for large KDP crystal machining, International Journal of Advanced Manufacturing Technology, 69(1), 237-244.

Mackerle J (1999). Finite-element analysis and simulation of machining: a bibliography (19761996), Journal of Materials Processing Technology, 86, 17-44.

Mackerle J (2003). Finite element analysis and simulation of machining: an addendum A bibliography (1996-2002), International Journal of Machine Tools \& Manufacture, 43, 103-114.

Martini A, Troncossi M (2016). Upgrade of an automated line for plastic cap manufacture based on experimental vibration analysis, Case Studies in Mechanical Systems and Signal Processing, 3, 28-33.

Myers A, Ford DG, Xu Q (2003). Finite element analysis of the structural dynamics of a vertical milling machine, Transactions on Engineering Sciences, 44, 431-440.

Mahdavinejad R (2005). Finite element analysis of machine and workpiece instability in turning, International Journal of Machine Tools \& Manufacture, 45, 753-760.

Mahnama M, Movahhedy MR (2010). Prediction of machining chatter based on FEM simulation of chip formation under dynamic conditions, International Journal of Machine Tools \& Manufacture, 50, 611-620.

Mahnama M, Movahhedy MR (2012). Application of FEM simulation of chip formation to stability analysis in orthogonal cutting process, Journal of Manufacturing Processes, 14, 188-194.

Marten HR (1962). The use of models for analysis of machine tool structures, International Journal of Machine Tool Design and Research, 2, 153-163.

Mießen MW, Müller W, Prößler EK (1976). Visual Representation of the Dynamic Behaviour of Machine Tool Structures, Annals of the CIRP, 25,1.

Mourtzis D, Doukas M, Bernidaki D (2014). Simulation in Manufacturing: Review and Challenges, Procedia CIRP, 25, $213-22$.

Nance RE, Sargent RG (2002). Perspectives on the Evolution of Simulation, Electrical Engineering and Computer Science, 50, 1, 161-172.

Negahban A, Smith JF (2014). Simulation for manufacturing system design and operation: Literature review and analysis, Journal of Manufacturing Systems, 33, 241-261.

Okubo N, Yoshida Y (1982). Application of Modal Analysis to Machine Tool Structures, Annals of the CIRP, 31.

Peters J, Mergeay M (1976). Dynamic Analysis of Machine Tools using Complex Modal Method, Annals of the CIRP, 25, 1.

Pavlovic A, Fragassa C (2016). Modelling the Viscoelasticity of Ceramic Tiles by Finite Element. Proceedings of the 8th Conference on Times of Polymers \& Composites. American Institute of Physics (AIP). 19-23th June 2016, Ischia (Italy). 1736, 4949749, doi: 10.1063/1.4949749

Rai JK, Xirouchakis P (2008). Finite element method based machining simulation environment for analysing part errors induced during milling of thin-walled components, International Journal of Machine Tools \& Manufacture, 48, 629-643.

Rad SZ (1997). Methods for updating numerical models in structural dynamics, imperial College of Science, Technology and Medicine, University of London

Ramana GV (1984). Optimum design of plano-milling machine structure using finite element analysis, Computers and Structures, 18, 2, 247-253. 
Sam Paul P, Raja P, Aruldhas P, Pringle S, Shaji E (2016). Effectiveness of particle and mass impact damping on tool vibration during hard turning process, Proceedings of the Institution of Mechanical Engineers, Part B: Journal of Engineering Manufacture, DOI: 10.1177/0954405416660995.

Snoeys R, Roesems D, Vanhonacker VP (1979). Survey of Modal Analysis Applications, Annals of the CIRP, 28, 2.

Tlusty J, Moriwaki T (1976). Computational Identification of Dynamic Structural Models, Annals of the CIRP, 25, 2.

Troncossi M, Troiani E, Rivola A (2009). Design optimization of a laser cutting machine by elastodynamic modeling, Proceedings of the 9th Biennial Conference on Engineering Systems Design and Analysis (ESDA), Volume 2, 7-9 July 2008, Haifa, Israel, 551-559.

Wang XL, Xu M and Hu YJ (2005). Finite Element Analysis of the Modal of Machine Tool [J]. Machine tool \& hydraulics, 2.

Wójcicki Z, Grosel J, Sawicki W, Majcher K, Pakos W (2015). Experimental (OMA) and numerical (FEM) modal analysis of ball mill foundations, Procedia Engineering, 111, 858863

Zanarini A, Catania G, Maggiore A, Meneghetti U (2002). Dynamic behavior analysis and optimisation of a rotary table transfer machine, Proceedings of the International Conference on Noise and Vibration Engineering (ISMA), 16-18 September 2002.

Zatarain M, Lejardi E, Egatia F (1998). Modular Synthesis of Machine Tools, Annals of the ClRP, 47, 1, 333-336. 